УДК 622.245 .5

\title{
МЕТОДИЧЕСКИЕ ПОДХОДЫ К ВЫБОРУ КОМПОНЕНТНОГО СОСТАВА И ПОКАЗАТЕЛЕЙ СВОЙСТВ ТЕХНОЛОГИЧЕСКИХ ЖИДКОСТЕЙ, ИСПОЛЬЗУЕМЫХ ДЛЯ ОТБОРА КЕРНА
}

\author{
Некрасова Ирина Леонидовна ${ }^{1}$, \\ Irina.Nekrasova@pnn.lukoil.com
}

\author{
Хвощин Павел Александрович1, \\ Pavel.Khvoschin@pnn.lukoil.com \\ Казаков Дмитрий Александрович1,
Dmitrij.Kazakov@pnn.lukoil.com
}

Торопицына Ирина Сергеевна ${ }^{1}$, Irina.Borovkova@pnn.lukoil.com

Гаршина Ольга Владимировна ${ }^{1}$, Olga.Garshina@pnn.lukoil.com

Предеин Андрей Александрович 1 , Andrej.Predein@pnn.lukoil.com

1 Филиал ООО «ЛУкОЙЛ-Инжиниринг» «ПермНИПИнефть» в г. Перми, Россия, 614015, г. Пермь, ул. Пермская, За.

\begin{abstract}
Актуальность. Основные изменения геохимических характеристик образцов породы на стадии отбора керна связаны с необоснованным выбором типа и показателей свойств промывочной жидкости, на стадии хранения - с низким качеством керноизолирующей жидкости. С иелью получения представительного керна требуемого качества, обладающего необходимой геологической информативностью, актуально обоснование состава и показателей свойств промывочных и керноизолирующих жидкостей, а также других параметров технологического процесса бурения.

Цель: определить и предложить критерии выбора состава и показателей свойств буровых растворов и керноизолирующих жидкостей, используемых для отбора керна, в зависимости от горно-геологических условий применения.

Объекты: буровые растворы на водной и углеводородной основе, безводные буровые растворы, керноизолирующие жидкости.

Методы: анализ и систематизация российского и зарубежного опыта теоретических и практических исследований в области отбора керна, фрильтрационные, реологические и другие методы исследования, предусмотренные ГОСТ $33213-2014$ (ISO 10414-1:2008) и ГОСТ 33697-2015 (ISO 10414-2:2011).

Результаты. Представлен анализ мирового опыта применения буровых растворов и керноизолирующих жидкостей в различных горно-геологических условиях бурения. Определены наиболее перспективные типы буровых растворов для отбора керна и керноизолирующих жидкостей с точки зрения сохранения исходных свойств отбираемой породы. Предложен алгоритм выбора типа и компонентного состава буровых растворов, используемых для отбора керна, в зависимости от иелей работ, категории пород по трудности отбора керна и видов геохимических исследований.
\end{abstract}

\section{Ключевые слова:}

Отбор керна, буровой раствор на водной основе, буровой раствор на углеводородной основе, керноизолирующая жидкость, геохимические исследования керна.

\section{Введение}

Керн является наиболее достоверным инструментом для изучения и подтверждения геологического строения нефтяных и газовых месторождений, уточнения результатов геологоразведочных работ. На основании данных по пористости, проницаемости, гранулометрическому составу, удельной поверхности, карбонатности, сжимаемости, насыщенности керна нефтью, газом и водой получают информацию о структуре, физико-механических и физикохимических свойствах продуктивных пластов. Отбор керна является сложной технологической операцией, требующей значительных финансовых и временных затрат, именно поэтому очень важно сохранить нативные свойства геологического материала.

Основные изменения геохимических характеристик образцов породы на стадии отбора керна связаны с необоснованным выбором типа и показателей свойств промывочной жидкости, на стадии хранения - с низким качеством керноизолирующей жидкости. С целью получения представительного керна требуемого качества, обладающего необходимой геологической информативностью, актуально обоснование состава и показателей свойств промывочных и керноизолирующих жидкостей, а также других параметров технологического процесса бурения.

\section{Обзор опыта применения буровых растворов для отбора керна}

От компонентного состава и фильтрационных свойств промывочной жидкости, используемой на этапе отбора, во многом зависит изменение естественной флюидонасыщенности керна. Буровые растворы на водной основе и прямые эмульсии (эмульсии «масло в воде»), состав фильтрата которых представлен водной фазой, приводят к увеличению значе- 
ния водонасыщенности керна. В то время как газообразные промывочные агенты, буровые растворы на углеводородной основе и обратные эмульсии (эмульсии «масло в воде») к изменению водонасыщенности керна в большинстве случаев не приводят [1].

Буровые растворы на водной основе (РВО) являются наиболее распространенным видом промывочных жидкостей на всех этапах строительства скважин, включая и отбор керна [2]. В настоящее время для отбора керна используют как специально разработанные рецептуры РВО [3], так и традиционные промывочные жидкости после их модификации различными реагентами (обработка гидрофобизатором, понизителем фильтрации, мелкодисперными кольматантами и др.) [4-6]. Данная практика наиболее распространена при бурении разведочных скважин, когда затраты на доставку дополнительных материалов, необходимых для приготовления специальной керноотборной жидкости, чрезмерно высоки. При использовании РВО для отбора керна особое внимание уделяется контролю показателя фильтрации, в том числе при высокой температуре и высоком давлении (НTHР - high temperature and high pressure) и толщине фильтрационной корки. Несмотря на широкую практику применения PBO для отбора керна, многие авторы $[1,7,8]$ высказывают опасение, что даже при условии достижения такими системами низких значений фильтрационных характеристик, контакт керна с РВО неизбежно приводит к нарушению сохранности его свойств. Это происходит как при подъеме керна на дневную поверхность, так и при транспортировке к месту дальнейшего анализа

Анализ мирового опыта применения промывочных жидкостей показывает устойчивую тенденцию роста объемов применения для отбора керна буровых растворов на углеводородной основе (РУО) [9]. При использовании растворов данного типа в породу под действием перепада давления фильтруется углеводородная жидкость либо эмульсия «вода в масле», родственные пластовой нефти и, в большинстве случаев, исключающие процессы эмульсеобразования и выпадения осадков в нефтенасыщенной части пород.

Авторы работ [7, 8, 10, 11] утверждают, что использование РУО для отбора керна способно сохранить его естественную водонасыщенность и проницаемость: изменение флюидонасыщенности порового пространства керна ограничивается частичным вы- теснением нефти, выделяющимся из неё газом и возможными незначительными потерями остаточной воды в процессе дегазации. Для обеспечения точности лабораторных исследований проб пород состав фильтрата бурового раствора для отбора керна должен существенно отличаться от состава пластового флюида. Поэтому, как и для водных систем буровых растворов, особые требования выдвигаются к химическому составу углеводородной основы РУО и показателю фильтрации НТНР. В настоящее время РУО для отбора керна имеются в арсенале многих ведущих сервисных компаний. Так, линейка специальных рецептур РУО для отбора керна (растворы серий Trucore, Versa) разработана компанией M-I SWACO [12]. Компания Baroid предлагает производить отбор керна на безглинистых инвертно-эмульсионных буровых растворах ACCOLADE, INNOVERT, INTERGRADE [13]. Указанные системы буровых растворов выделяются на фоне традиционных РУО отсутствием в их рецептуре органофильного бентонита, способного кольматировать поровое пространство породы, что снижает их негативное воздействие на свойства керна.

Следует отметить, что применение традиционных буровых растворов для отбора керна, как на водной, так и на углеводородной основе, может приводить к нарушению (изменению) его остаточной водонасыщенности, что, в свою очередь, затрудняет интерпретацию данных по нефтенасыщенности продуктивного пласта, получаемых в ходе исследования отобранного кернового материала. Так, авторы работы [14] отмечают, что системы буровых растворов с низким значением показателя фильтрации позволяют минимизировать проникновение раствора в керн, но смачиваемость породы и ее флюидонасыщенность могут изменяться при противоточном проникновении фильтрата бурового раствора и/или его диффузии до начала анализа керна.

Использование РУО с минимальным содержанием воды (не более 3 \%) либо полностью безводных систем способно обеспечить сохранение естественного соотношения подвижных флюидов в керновом материале [15]. Сводная информация по функциональному назначению и химической природе реагентов, используемых в современных рецептурах безводных буровых растворов, подготовленная на основании анализа литературных источников [16-18], приведена в табл. 1.

Таблица 1. Реагенты, используемые в рецептурах безводных буровых растворов

Table 1. Reagents used in waterless drilling fluid formulations

\begin{tabular}{|c|c|}
\hline $\begin{array}{c}\text { Функциональное назначение реагентов } \\
\text { Functional purpose of reagents } \\
\end{array}$ & $\begin{array}{c}\text { Химическая природа реагентов } \\
\text { Chemical nature of reagents }\end{array}$ \\
\hline $\begin{array}{l}\text { Углеводородная основа } \\
\text { Oil base }\end{array}$ & $\begin{array}{l}\text { Дизельное топливо, минеральные масла, безводная нефть } \\
\text { Diesel fuel, mineral oils, anhydrous oil }\end{array}$ \\
\hline Эмульгатор/Emulsifier & $\begin{array}{l}\text { Жирные кислоты + известь, амиды и имиды жирных кислот } \\
\text { Fatty acids + lime, amides and imides of fatty acids }\end{array}$ \\
\hline $\begin{array}{l}\text { Структурообразователь } \\
\text { Rheology modifier }\end{array}$ & $\begin{array}{l}\text { Органофильный бентонит (во многих рецептурах совместно с полярной активирую- } \\
\text { щей добавкой), соли жирных кислот } \\
\text { Organophilic bentonite (in many muds together with a polar activating additive), fatty acid salts }\end{array}$ \\
\hline $\begin{array}{l}\text { Понизитель фильтрации } \\
\text { Filtration modifier }\end{array}$ & $\begin{array}{l}\text { Гильсонит, сульфированный/окисленный битум, полимерные реагенты на основе мо- } \\
\text { дифицированного латекса } \\
\text { Gilsonite, sulfonated/oxidized bitumen, polymer reagents based on modified latex }\end{array}$ \\
\hline $\begin{array}{l}\text { Утяжелитель } \\
\text { Weighting agent }\end{array}$ & $\begin{array}{l}\text { Разнофракционный карбонат кальция, барит } \\
\text { Multi-factional calcium carbonate, barite }\end{array}$ \\
\hline
\end{tabular}


В целом по результатам обзора можно отметить отсутствие единого подхода со стороны геологических служб и разработчиков буровых растворов к регламентированию требований к составу и показателям свойств буровых растворов, используемых для отбора керна.

\section{Методические подходы к выбору типа и показателей свойств буровых растворов для отбора керна}

В условиях многообразия существующих рецептур буровых растворов, перед специалистами проектных и геологических организаций встает проблема выбора компонентного состава и показателей свойств бурового раствора для отбора керна в конкретных геологотехнических условиях месторождения [19-21].

При обосновании выбора компонентного состава бурового раствора для отбора керна должны учитываться следующие критерии:

- цели отбора керна и конкретный перечень планируемых геохимических анализов керна;

- литологический состав пород в интервале отбора керна, в том числе классификация пород по категориям буримости;
- наличие/отсутствие и виды осложнений при строительстве предыдущих скважин на конкретном месторождении или в аналогичных геологотехнических условиях бурения.

На основании многолетних исследований и опыта работы Всесоюзный научно-исследовательский институт буровой техники подразделил все горные породы на 4 категории по трудности отбора керна, при этом под термином «трудность отбора керна» подразумевается способность породы сохранять исходную структуру образца керна в процессе его выбуривания и подъема на дневную поверхность [22]. Наибольшую трудность в сохранении керна и его максимального выноса вызывает отбор в рыхлых, набухающих, перемятых горных породах, растворяющихся в промывочной жидкости.

Требования к выбору типа бурового раствора для отбора керна в зависимости от категории буримости пород приведены в табл. 2.

Таблица 2. Выбор бурового раствора в зависимости от категории горных пород по трудности отбора керна

Table 2. Choice of drilling fluid depending on the category of rocks by the difficulty of coring

\begin{tabular}{|c|c|c|}
\hline $\begin{array}{l}\text { Категория пород по } \\
\text { буримости (ВНИИБТ) } \\
\text { Rock category by drilla- } \\
\text { bility (VNIIBT) }\end{array}$ & $\begin{array}{c}\text { Краткая характеристика горных пород } \\
\text { Brief description of rocks }\end{array}$ & $\begin{array}{c}\text { Рекомендуемый тип бурового раствора } \\
\text { для отбора керна } \\
\text { Recommended type of drilling mud } \\
\text { for core sampling }\end{array}$ \\
\hline I & $\begin{array}{l}\text { Связные, монолитные и слаботрещиноватые } \\
\text { Cohesive, monolithic and slightly fractured }\end{array}$ & $\begin{array}{l}\text { Буровой раствор на водной основе с ограничен- } \\
\text { ной фильтрацией } \\
\text { Water-based drilling mud with limited filtration }\end{array}$ \\
\hline II & $\begin{array}{l}\text { Связные, средне и сильнотрещиноватые; склонные к си- } \\
\text { стематическому самозаклиниванию. Не размываемые, } \\
\text { но разрушаемые потоком на кусочки по трещинам. Раз- } \\
\text { рушаемые вибрациями керноотборного инструмента } \\
\text { Connected, medium and strongly fractured; prone to sys- } \\
\text { tematic self-jamming. Not eroded, but destroyed by the } \\
\text { flow into pieces along the cracks. Destroyed by vibrations } \\
\text { of the core-collecting tool }\end{array}$ & $\begin{array}{l}\text { Высокоингибированный буровой раствор на вод- } \\
\text { ной основе с комплексом микрокольматантов } \\
\text { Highly inhibited water-based drilling mud with a } \\
\text { complex of microcolmatants }\end{array}$ \\
\hline II-III & $\begin{array}{l}\text { Растворимые соли, засолоненный коллектор } \\
\text { Soluble salts, blocked collector }\end{array}$ & $\begin{array}{l}\text { Соленасыщенный буровой раствор на водной основе } \\
\text { Water-based unsaturated drilling mud }\end{array}$ \\
\hline III & $\begin{array}{l}\text { Слабосвязные. Легко разрушаемые или размываемые по- } \\
\text { током, а также с набухающими глинистыми частицами } \\
\text { Weakly connected. Easily destroyed or eroded by the } \\
\text { flow, as well as with swollen clay particles }\end{array}$ & $\begin{array}{l}\text { Буровой раствор на углеводородной основе } \\
\text { Oil-based drilling mud }\end{array}$ \\
\hline IV & $\begin{array}{l}\text { Слабосвязные, несвязные, рыхлые, сыпучие, плы- } \\
\text { вуны. Размываемые потоком жидкости } \\
\text { Weakly connected, incoherent, loose, quicksand. Erod- } \\
\text { ed by fluid flow }\end{array}$ & $\begin{array}{l}\text { Буровой раствор на углеводородной основе, плот- } \\
\text { ность которого рассчитана по результатам постро- } \\
\text { ения геомеханической модели устойчивости пород } \\
\text { Oil-based drilling mud, the density of which is calcu- } \\
\text { lated based on the results of the rock stability geo- } \\
\text { mechanical model }\end{array}$ \\
\hline
\end{tabular}

При отборе керна в интервалах, представленных породами III категории буримости и содержащими в своем составе гидратируемые глинистые минералы, склонные к набуханию и диспергированию, предъявляются повышенные требования к ингибирующим свойствам бурового раствора с целью предотвращения изменения физико-химических свойств керна и сохранения устойчивости стенок на всем протяжении отбора керна и последующего бурения. Если на месторождении (либо в аналогичных геологотехнических условиях) имеется отрицательный опыт бурения скважин на буровых растворах на водной ос- нове, рекомендуется для отбора керна использовать буровой раствор на углеводородной основе.

Отбор керна в интервалах слабосвязных, неконсолидированных пород IV категорий буримости необходимо производить с применением буровых растворов на углеводородной основе, значения статической и эквивалентной циркуляционной плотности которых устанавливаются по результатам построения предбуровой геомеханической модели устойчивости пород интервала отбора керна с проведением гидравлического расчета промывки, расчета скоростей спуско-подъемных операций с учетом эффектов поршневания/свабирования. 
Если программой работ по отбору керна предусмотрено определение начальной нефтенасыщенности продуктивных пластов прямым методом на керне (анализ керна экстракционно-дистилляционным методом), отбор керна рекомендуется производить с использованием безводного бурового раствора на углеводородной основе (с содержанием водной фазы не более 3 об. \%). В составе безводного бурового раствора должны отсутствовать реагенты, влияющие на значения флюидонасыщенности керна: амино- и амидосодержащие органические соединения, реагенты на основе природных битумов и спиртов. По результатам исследований реагенты из указанных групп химических соединений могут существенно снизить значение коэффициента остаточной водонасыщенно- сти керна. В частности, влияние на водонасыщенность керна органических спиртов связано с их способностью к поглощению воды, амидов и аминов жирных кислот - с их эмульгирующей способностью по отношению к воде, содержащейся в поровом пространстве керна [23, 24].

С целью обеспечения достоверной интерпретации геофизической информации в составе всех типов буровых растворов для отбора керна должны отсутствовать химические реагенты, отрицательно влияющие на работу телеметрического и каротажного оборудования (например, гематит, магнетит).

Предлагаемый алгоритм выбора компонентного состава буровых растворов для отбора керна приведен на рисунке.

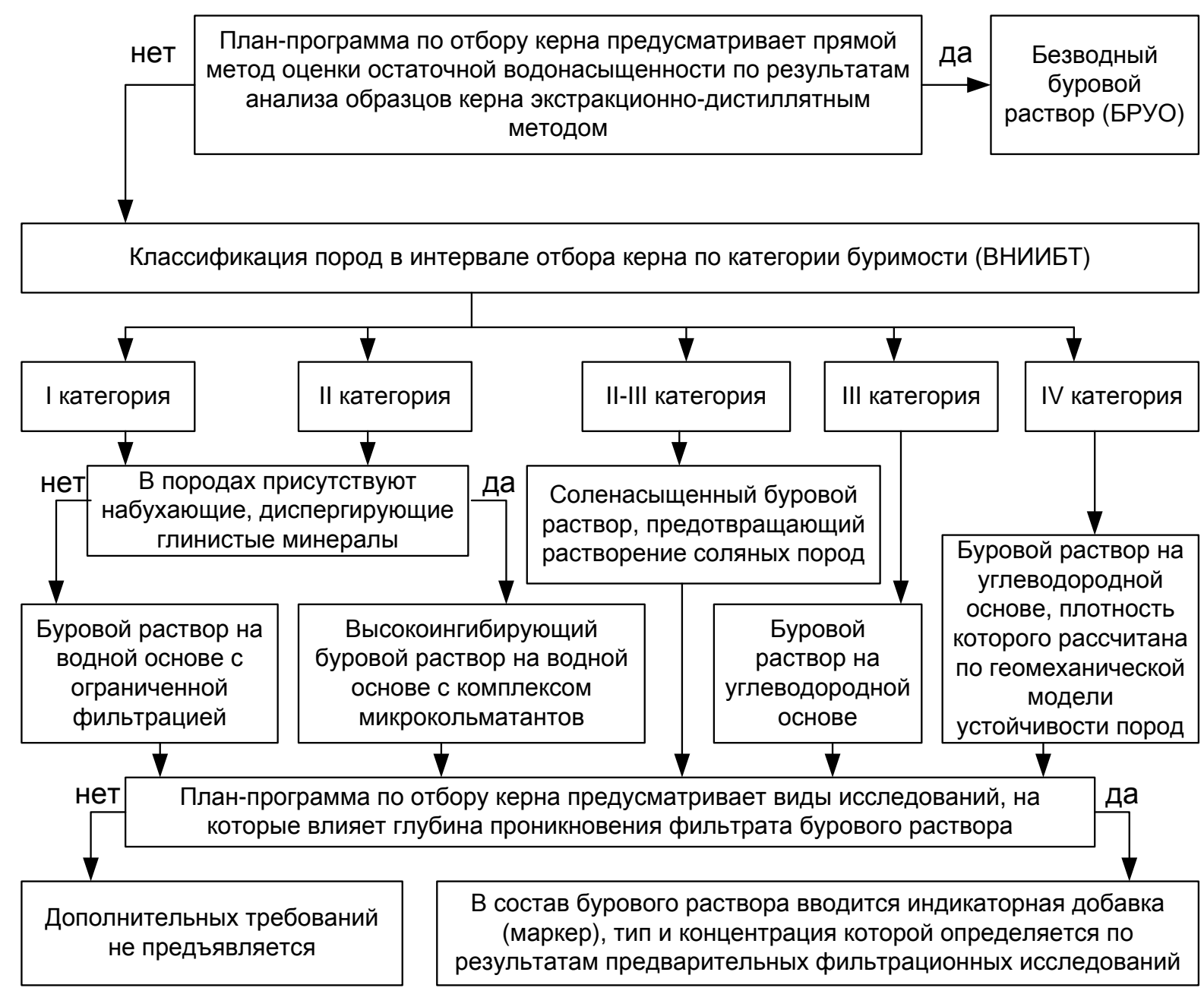

Рисунок. Алгоритм выбора бурового раствора для отбора керна

Figure. Algorithm for selection of drilling fluid for coring

Дополнительные требования к компонентному составу бурового раствора для обеспечения репрезентативности керна в зависимости от целей работ по отбору керна и видов геохимических исследований приведены в табл. 3 .

Буровые растворы при проникновении внутрь керна в процессе отбора оказывают влияние на естественное флюидонасыщение пород. Если отбор керна производится с целью оценки остаточной водонасы- щенности пород, соотношения флюидов в породе, величины капиллярного давления, рекомендуется дополнительный ввод в состав бурового раствора индикаторных добавок (маркеров), позволяющих проводить анализ глубины проникновения фильтрата раствора в керн.

К химическим соединениям, которые используются в качестве индикаторных добавок в буровых растворах, предъявляются следующие основные требования: 
- индикаторные добавки должны отличаться по своей химической природе от остальных веществ, присутствующих в буровом растворе, пластовых флюидах и вскрываемых горных породах;

- д должны быть растворимы в буровом растворе и не склонны к образованию осадков в условиях температур и давлений, при которых используется буровой раствор;

- не должны адсорбироваться на частицах твёрдой фазы бурового раствора, поверхностях пробоотборного оборудования, резервуаров для буровых растворов, насосов и трубопроводов, бурильных труб, скважинных инструментов и насоснокомпрессорных труб;

- не должны адсорбироваться на поверхностях горных пород, контактирующих с буровым раствором;

- должны быть химически стабильными в условиях температур и давлений, при которых используется буровой раствор;

- должна существовать возможность количественного определения индикаторной добавки с низким пределом обнаружения и высокой степенью точности в исследуемых образцах кернового материала либо пластовых флюидов.

Таблица 3. Требования к компонентному составу буровых растворов в зависимости от видов геохимического анализа керна

Table 3. Requirements for the component composition of drilling fluids depending on the types of geochemical analysis of the core

\begin{tabular}{|c|c|}
\hline $\begin{array}{c}\text { Показатели, определяемые } \\
\text { при геохимическом анализе керна } \\
\text { Indicators determined by the core geochemical analysis }\end{array}$ & $\begin{array}{l}\text { Требования к буровым растворам } \\
\text { Drilling fluid requirements }\end{array}$ \\
\hline Пористость/Porosity & \multirow{4}{*}{$\begin{array}{l}\text { Дополнительных требований не предъявляется } \\
\text { No additional requirements }\end{array}$} \\
\hline Проницаемость/Permeability & \\
\hline Литологический состав & \\
\hline $\begin{array}{l}\text { Коэффициент остаточной газонасыщенности } \\
\text { Residual gas saturation coefficient }\end{array}$ & \\
\hline $\begin{array}{l}\text { Смачиваемость } \\
\text { Wettability }\end{array}$ & $\begin{array}{l}\text { В составе бурового раствора должны отсутствовать поверхностно-активные } \\
\text { компоненты, приводящие к изменению смачиваемости поверхности порово- } \\
\text { го пространства пород } \\
\text { The composition of the drilling mud should be free of surface-active components } \\
\text { that lead to a change in the wettability of the surface of the pore space of rocks }\end{array}$ \\
\hline $\begin{array}{l}\text { Содержание органических веществ, условия осад- } \\
\text { конакопления и термическая зрелость нефтемате- } \\
\text { ринской породы } \\
\text { Organic matter content, sedimentation conditions, and } \\
\text { thermal maturity of the oil source rock }\end{array}$ & $\begin{array}{l}\text { В составе бурового раствора должны отсутствовать реагенты на основе био- } \\
\text { маркеров (терпанов и стеранов), являющихся уникальными признаками, поз- } \\
\text { воляющими судить о возрасте, литологических характеристиках, содержании } \\
\text { органического вещества и термической зрелости нефтематеринской породы } \\
\text { Composition of drilling mud should be free of reagents based on biomarkers (terpanes } \\
\text { and steranes, which are unique features that allow us to judge the age, lithological } \\
\text { characteristics, organic matter content and thermal maturity of the oil source rock }\end{array}$ \\
\hline $\begin{array}{l}\text { Капиллярное давление } \\
\text { Capillary pressure }\end{array}$ & $\begin{array}{l}\text { В состав бурового раствора вводятся поверхностно-активные вещества, по- } \\
\text { нижающие поверхностное натяжение на границе «фильтрат бурового рас- } \\
\text { твора - пластовая нефть» } \\
\text { Surfactants are introduced into the composition of the drilling mud, which reduce } \\
\text { the surface tension at the boundary «filtrate of drilling mud - reservoir oil» }\end{array}$ \\
\hline $\begin{array}{l}\text { Коэффициент остаточной водонасыщенности, со- } \\
\text { отношение вода/нефть, капиллярное давление } \\
\text { Residual water saturation coefficient, water/oil ratio, } \\
\text { capillary pressure }\end{array}$ & $\begin{array}{l}\text { Буровой раствор должен сохранять естественную водонасыщенность пород, } \\
\text { рекомендуется применение буровых растворов на углеводородной основе с } \\
\text { низким показателем фильтрации } \\
\text { The drilling mud should retain the natural water saturation of the rocks, it is rec- } \\
\text { ommended to use oil-based drilling fluids with a low filtration rate }\end{array}$ \\
\hline $\begin{array}{l}\text { Компонентный состав содержащихся в керне нефти } \\
\text { и газа методом газовой хроматографии } \\
\text { Composition of oil and gas contained in the core by gas } \\
\text { chromatography }\end{array}$ & $\begin{array}{l}\text { В составе бурового раствора должны отсутствовать ароматические углево- } \\
\text { дороды и легкие углеводороды }\left(\mathrm{C}_{1}-\mathrm{C}_{10}\right) \text {, маскирующие углеводороды ука- } \\
\text { занных классов, содержащиеся в породе } \\
\text { Composition of the drilling fluid must be free of aromatic hydrocarbons and light } \\
\text { hydrocarbons }\left(\mathrm{C}_{1}-\mathrm{C}_{10}\right) \text { that mask the hydrocarbons of the specified classes con- } \\
\text { tained in the rock }\end{array}$ \\
\hline
\end{tabular}

Как показывает анализ литературы [25, 26], в качестве индикаторных добавок в буровых растворах могут быть использованы следующие химические вещества:

- флуоресцентные органические соединения;

- фторсодержащие органические соединения;

- неорганические ионы;

- комплексные соединения металлов.

\section{Флуоресцентные органические соединения}

Флуоресцентные органические вещества представляют собой полициклические ароматические соединения. Они характеризуются полярным характером молекул и поэтому водорастворимы. Оптические свойства этих соединений и, следовательно, их флуорометрические характеристики чувствительны к различным свойствам водных растворов, особенно к рН, ионной силе и температуре. Одним из наиболее распространённых флуоресцентных индикаторов является флуоресцеин, который обычно применяется в виде натриевой соли (уранина), имеющей желтоватозеленую флуоресценцию. Анализ данного вещества в исследуемых образцах проводят с помощью флуориметрии, которая представляет собой достаточно простой инструментальный метод флуоресцентной спектрофотометрии с низким пределом обнаружения (около 0,01 мкг/л). Также в качестве флуоресцентных индикаторных добавок в буровых растворах могут 
быть использованы родаминовые красители (родамин WT, родамин В, родамин C, сульфорамин В, сульфорамин G), эозин, 7-амино-1,3-нафталиндисульфоновая кислота, АГ-кислота.

\section{Фторсодержащие органические соединения}

Синтетические фторсодержащие органические соединения обладают повышенной химической стабильностью и не встречаются в горных породах и пластовых флюидах. В качестве фторорганических индикаторных добавок могут быть использованы производные фторбензойной кислоты, а также перфторированные углеводороды.

Производные фторбензойной кислоты представляют собой полярные циклические органические соединения, хорошо растворимые в воде. Основное внимание при применении в качестве индикаторов уделяется дифтор-, трифтор-, тетрафтор- и пентафторизомерам бензойной кислоты, в частности:

- изомерам дифторбензойной кислоты;

- изомерам трифторбензойной кислоты;

- изомерам тетрафторбензойной кислоты;

- изомерам пентафторбензойной кислоты;

- изомерам трифторметилбензойной кислоты.

Для количественного определения производных фторбензойной кислоты в исследуемых образцах, как правило, используется высокоэффективная жидкостная хроматография (ВЭЖХ) с УФ-детектором. Предел обнаружения составляет около 1 мкг/л.

Перфторированные углеводороды представляют собой высокоинертные неполярные соединения, хорошо растворимые в органических растворителях. Для анализа перфторированных углеводородов используется газовая хроматография, обеспечивающая предел обнаружения около 40 нг/л.

Неорганические ионы

В качестве индикаторных добавок в буровых растворах могут быть использованы ионы неорганических электролитов. Наиболее часто для этой цели применяют следующие ионы:

- ионы лития;

- ионы калия;

- галогенид-ионы (хлорид, бромид, йодид-ионы);

- нитрат-ионы;

- тиоцианат-ионы.

Для количественного определения индикаторных ионов в исследуемых образцах используется ионная хроматография с пределом обнаружения 3-10 мкг/мл.

В буровых растворах, содержащих гидратированные глинистые минералы, ионы имеют тенденцию сорбироваться на частицах твёрдой фазы, и поэтому при дозировании индикатора необходимо учитывать влияние ионного обмена.

\section{Комплексные соединения металлов}

В качестве индикаторных добавок могут быть использованы стабильные комплексные соединения металлов (Co, Cr, In, Zn) с полидентантными лигандами, такими как этилендиаминтетрауксусная кислота, ди- этилентриаминпентауксусная кислота, нитрилотриуксусная кислота и др. Основным преимуществом применения индикаторов на основе тяжелых металлов является сверхнизкий предел обнаружения (от 0,1 нг/г), обеспечиваемый при применении нейтронноактивационного анализа исследуемых образцов.

Важную роль в обеспечении качества кернового материала играет выбор не только типа бурового раствора, но также и показателей его технологических и специальных свойств. Особое внимание уделяют контролю плотности, фильтрационных и реологических свойств бурового раствора.

С целью предотвращения «загрязнения» порового пространства керна твердой фазой и фильтратом бурового раствора для отбора керна допускается применение исключительно буровых растворов с ограниченной фильтрацией. Основные требования к показателям фильтрационных свойств буровых растворов, используемых для отбора керна, сформулированные на основе анализа лучших мировых практик, приведены в табл. 4.

Реологические свойства бурового раствора (пластическая вязкость, динамическое напряжение сдвига, статическое напряжение сдвига) определяют качество очистки ствола скважины от выбуренной породы, значение эквивалентной циркуляционной плотности раствора, величину гидродинамических давлений, седиментационную (к оседанию утяжелителя) и агрегативную (к слипанию частиц дисперсной фазы) устойчивость раствора во времени. Значения показателей реологических свойств бурового раствора, используемого, в том числе, для отбора керна, определяются по результатам гидравлических расчетов промывки ствола скважины с учетом максимальной циркуляционной температуры бурового раствора. При отборе керна в условиях повышенных пластовых температур буровой раствор должен также сохранять агрегативную и седиментационную устойчивость, стабильность реологических свойств при температуре, соответствующей максимальной пластовой.

Дополнительным требованием для буровых растворов на углеводородной основе, используемых для отбора керна, является обеспечение пожаробезопасности. РУО должен иметь температуру вспышки, на $50{ }^{\circ} \mathrm{C}$ превышающую максимально ожидаемую температуру раствора на устье скважины. При несоблюдении указанного требования обязательна установка на устье скважины специальных датчиков контроля концентрационных пределов распространения пламени [27].

Для буровых растворов на водной основе в случае необходимости определения физико-химических свойств пластовых флюидов, содержащихся в образцах керна, дополнительным требованием является контроль удельного электрического сопротивления бурового раствора. Точное значение удельного электрического сопротивления используется для внесения соответствующих корректировок при интерпретации полученных геохимических данных при исследовании керна. 
Таблица 4. Требования к показателям фильтрационных свойств буровых растворов

Table 4. Requirements for filtration properties of drilling fluids

\begin{tabular}{|c|c|}
\hline $\begin{array}{l}\text { Показатель фильтрационных свойств } \\
\text { Indicator of filtration properties } \\
\end{array}$ & $\begin{array}{c}\text { Требования к значению показателя } \\
\text { Requirements for the indicator value }\end{array}$ \\
\hline \multicolumn{2}{|c|}{ Для буровых растворов на водной основе/For water-base mud } \\
\hline $\begin{array}{l}\text { Показатель фильтрации при } \Delta \mathrm{P}=0,7 \mathrm{MПа} \\
\text { Filtration rate at } \Delta \mathrm{P}=0,7 \mathrm{MPa}\end{array}$ & $\leq 5 \mathrm{~cm}^{3} / 30 \mathrm{Mин} / \leq 5 \mathrm{~cm}^{3} / 30 \mathrm{~min}$ \\
\hline $\begin{array}{l}\text { Показатель фильтрации при температуре, соответствую- } \\
\text { щей максимальной пластовой на месторождении, при } \\
\Delta \mathrm{P}=3,5 \mathrm{MПа} \\
\text { Filtration rate at the maximum reservoir temperature at } \\
\Delta \mathrm{P}=3,5 \mathrm{MPa}\end{array}$ & $\leq 0 \mathrm{~cm}^{3} / 30 \mathrm{Mин} / \leq 10 \mathrm{~cm}^{3} / 30 \mathrm{~min}$ \\
\hline Толщина фильтрационной корки/Mud cake thickness & $\leq 1 \mathrm{MM} / \mathrm{mm}$ \\
\hline \multirow{2}{*}{$\begin{array}{l}\text { Состав фильтрата } \\
\text { Filtrate composition }\end{array}$} & $\begin{array}{l}\text { не должен образовывать нерастворимых осадков при контакте с пла- } \\
\text { стовой водой и высоковязких эмульсий при контакте с пластовой } \\
\text { нефтью месторождения } \\
\text { it should not form insoluble sediments in contact with reservoir water and } \\
\text { high-viscosity emulsions in contact with reservoir oil of the field }\end{array}$ \\
\hline & $\begin{array}{l}\text { не должен приводить к набуханию глинистых минералов в породе (в } \\
\text { случае их наличия в составе пород интервала отбора керна) } \\
\text { it should not lead to swelling of clay minerals in the rock (if they are pre- } \\
\text { sent in the rocks of the core selection interval) }\end{array}$ \\
\hline $\begin{array}{l}\text { Поверхностное натяжение на границе «фильтрат бурово- } \\
\text { го раствора - пластовая нефть месторождения» } \\
\text { Surface tension at the «drilling mud filtrate - reservoir oil field» }\end{array}$ & $0,1 \ldots 5 \mathrm{MH} / \mathrm{M} / \mathrm{mN} / \mathrm{m}$ \\
\hline \multicolumn{2}{|c|}{ Для буровых растворов на углеводородной основе/For oil-base mud } \\
\hline $\begin{array}{l}\text { Показатель фильтрации при } \Delta \mathrm{P}=0,7 \mathrm{MПа} \\
\text { Filtration rate at } \Delta \mathrm{P}=0,7 \mathrm{MPa}\end{array}$ & $\leq 1 \mathrm{~cm}^{3} / 30 \mathrm{Mин} / \leq 1 \mathrm{~cm}^{3} / 30 \mathrm{~min}$ \\
\hline $\begin{array}{l}\text { Показатель фильтрации при температуре, соответствую- } \\
\text { щей максимальной пластовой на месторождении, при } \\
\Delta \mathrm{P}=3,5 \mathrm{MПа} \\
\text { Filtration rate at the maximum reservoir temperature at } \\
\Delta \mathrm{P}=3,5 \mathrm{MPa}\end{array}$ & $\leq 5 \mathrm{~cm}^{3} / 30 \mathrm{Mин} / \leq 5 \mathrm{~cm}^{3} / 30 \mathrm{~min}$ \\
\hline Толщина фильтрационной корки/Mud cake thickness & $\leq 1 \mathrm{MM} / \mathrm{mm}$ \\
\hline \multirow{2}{*}{$\begin{array}{l}\text { Состав фильтрата } \\
\text { Filtrate composition }\end{array}$} & $\begin{array}{l}\text { не должен содержать в своем составе водную фазу (капли воды) } \\
\text { it should not contain an aqueous phase (water droplets) }\end{array}$ \\
\hline & $\begin{array}{l}\text { не должен образовывать высоковязких эмульсий при контакте с пла- } \\
\text { стовой водой } \\
\text { it should not form high-viscosity emulsions in contact with reservoir water }\end{array}$ \\
\hline
\end{tabular}

\section{Методические подходы к выбору} керноизолирующих жидкостей

В настоящее время на некоторых месторождениях начинает внедряться технология отбора изолированного керна, направленная на обеспечение максимальной защиты керна от контакта с промывочной жидкостью, начиная с момента выбуривания его на забое. Реализуется технология за счет использования специального керноотборного снаряда изолирующего типа, в котором внутренняя полость керноприемной трубки заполнена керноизолирующей жидкостью (КИЖ), образующей защитное покрытие на поверхности керна и предотвращающей контакт керна с промывочной жидкостью и воздухом [28]. Использование КИЖ обеспечивает минимизацию процесса фильтрации промывочной жидкости в керн на уровне не более 5-10 мм за счет ограничения времени контакта керна с промывочной жидкостью до нескольких секунд.

Для изоляции керна используется, как правило, высоковязкая жидкость с практически нулевой мгновенной фильтрацией. Особенно актуально использование высоковязкой жидкости для слабо сцементированных пород с низким значением предела прочности на сжатие. Высоковязкая жидкость стабилизирует слабо сцементированные породы и повышает целостность керна, выступая в качестве слабопроницаемого барьера [29].
Известно применение в качестве КИЖ растворов высокомолекулярных веществ на водной, спиртовой, углеводородной основе [30], загущенных органических жидкостей [31]. Использование в качестве КИЖ безводных высоковязких гелей помогает не только защитить керн в процессе его транспортировки и хранения, но и дополнительно снизить коэффициент трения в системе «горная порода - стенки керноприемной трубы».

При выборе компонентного состава КИЖ с целью предотвращения процессов эмульсе- и осадкообразования важную роль играет совместимость КИЖ и бурового раствора, используемого для отбора керна. Для обеспечения совместимости рекомендуется использовать единый тип жидкостей: если отбор керна проводился с применением PВО - использовать КИЖ на водной основе, с РУО - использовать КИЖ на углеводородной основе. Возможно применение КИЖ на основе неуглеводородных органических жидкостей после проведения предварительных лабораторных исследований на совместимость контактирующих между собой жидкостей.

Керноизолирующая жидкость должна обладать способностью к сохранению керна как носителя информации в течение неопределенно долгого времени. Особенно актуально применение КИЖ при отборе керна в интервалах слабосвязных, неконсолидированных пород IV категории буримости. При отборе керна в интервалах, представленных породами III ка- 
тегории буримости и содержащих в своем составе гидратируемые глинистые минералы, рекомендуется применять безводные КИЖ, в том числе на углеводородной основе. При отборе керна в интервалах нефтематеринских пород II категории буримости (доманик и др.) использование керноизолирующей жидкости на углеводородной основе, наоборот, не рекомендуется с целью исключения искажения результатов геохимического исследования керна.

По результатам обзора научно-технической литературы можно выделить следующие основные требования к компонентному составу и свойствам КИЖ:

- реагенты, входящие в состав КИЖ, должны быть инертны по отношению к породе и поровым флюидам: нефти и воде;

- в составе должны отсутствовать реагенты, способные вызывать образование осадка и, как следствие, необратимую кольматацию порового пространства образцов керна;

- КИЖ должна стабилизировать породы, имеющие низкие значения предела прочности на сжатие, и повышать целостность керна;

- при отборе керна для оценки коэффициентов водо- и нефтенасыщенности КИЖ не должна содержать свободную воду и реагенты, влияющие на значение остаточной водонасыщенности керна;

- при отборе керна для оценки типа смачиваемости пород КИЖ не должна иметь в составе реагенты, приводящие к изменению смачиваемости поверхности порового пространства пород;

- температура замерзания КИЖ должна быть ниже, чем минимальное значение температуры окружающей среды при хранении и транспортировке керна (вода при заморозке может привести к разрыву керна, что нарушит его структуру);

- КИЖ должна быть полностью совместима с буровым раствором и его фильтратом, не образовывать на границе контакта осадков и эмульсий;

- при отборе керна в интервалах, породы которых содержат гидратируемые глинистые минералы, КИЖ должна обладать повышенными ингибирующими свойствами с целью предотвращения изменения физико-химических свойств керна;

- КИЖ должна иметь высокую вязкость при максимальной пластовой температуре: пластическая вязкость должна составлять не менее 50 мПағс;

\section{СПИСОК ЛИТЕРАТУРЫ}

1. Серебряков А.О. Синергия геологоразведочных технологий исследования природных ресурсов морских акваторий: монография. - М.: Изд-во «КноРус», 2017. - 228 с.

2. Ashena R., Thonhauser G. Coring methods and systems. - Cham: Springer International Publ., 2018. - 269 p.

3. First global successful large diameter pressurized coring application using HPWBM: Kuwait case history / R. Stewart, T. Osman, T. Reda, A. Al-Ajmi, A. Al-Rushoud, A. Gohain, F. Khatib, H. Al-Haj, F. Al-Naqa, F. Al-Mutawa, M. Al-Gharib, H. Shinde, A. Al-Mekhalef // Paper SPE 192694-MS. Abu Dhabi International Petroleum Exhibition \& Conference. - Abu Dhabi, 12-15 November, 2018. DOI: 10.2118/192694-MS.

4. Карпов Ю.И., Аюпов Р.Ю., Фасхутдинов Р.Ш. Совершенствование техники и технологии бурения с отбором керна в Нурлатском УБР // Бурение и нефть. - 2006. - № 5. - С. 18-20.
- КИЖ должна сохранять агрегативную и кинетическую устойчивость, стабильность реологических и фильтрационных параметров при максимальной пластовой температуре месторождения;

- на этапе приемки и подготовки керна для проведения геохимических исследований КИЖ должна легко очищаться с поверхности керна методом сухого вытирания.

Большое внимание уделяется контролю фильтрационных свойств керноизолирующих жидкостей. Предпочтительно, чтобы КИЖ имела практически нулевое значение показателя мгновенной фильтрации, определяемого согласно ГОСТ 33213-2014 (ISO 10414-1:2008. Приложение I). При применении КИЖ на месторождениях, для которых характерны повышенные пластовые температуры, показатель фильтрации НТНР при максимальной пластовой температуре должен составлять для жидкостей на водной основе не более $10 \mathrm{~cm}^{3} / 30$ мин, для жидкостей на углеводородной основе - не более $5 \mathrm{~cm}^{3} / 30$ мин.

Подбор типа и компонентного состава КИЖ предлагается проводить по результатам оценки указанных выше показателей на стадии предварительных лабораторных исследований в свободном объеме и на природном керновом материале.

\section{Заключение}

Выбор технологических жидкостей для отбора керна должен определяться требованиями к сохранению исходных свойств отбираемого кернового материала, свойствами породы, свойствами технологической жидкости, а также конкретными условиями бурения с отбором керна. Учёт перечисленных факторов может позволить провести целенаправленный выбор технологических жидкостей, обеспечивающих сохранение необходимого комплекса нативных свойств породы при отборе керна. Определены наиболее перспективные типы буровых растворов для отбора керна и керноизолирующих жидкостей с точки зрения сохранения исходных свойств отбираемой породы. Предложен алгоритм выбора типа и компонентного состава буровых растворов, используемых для отбора керна, в зависимости от целей работ, категории пород по трудности отбора керна и видов геохимических исследований.

5. Юсупов И.Г., Хаминов Н.И., Бачков А.П. Исследование техногенного воздействия первичного вскрытия пластов на их коллекторские свойства отбором радиальных кернов // Сборник научных трудов ТатНИПИнефть. - М.: ОАО «ВНИИОЭНГ», 2009. - С. 187-197.

6. Rathmell J.J., Gremley R.R., Tibbitts G.A. Field applications of low invasion coring // Paper SPE 27045-MS. SPE Latin America/Caribbean Petroleum Engineering Conference. - Buenos Aires, 27-29 April, 1994. DOI: 10.2523/27045-MS.

7. Буровой раствор на углеводородной основе: пат. 2208034 Российская Федерация, С09K 7/06. № 2001128580/03; заявл. 22.10.2001; опубл. 10.07.2003. URL: https://www1.fips.ru/ registers-doc-view/fips_servlet (дата обращения 01.10.2021).

8. Буровой раствор на углеводородной основе: пат. № 2208035 Российская Федерация, С09К 7/06. № 2001133726/03; заявл. 
11.12.2001; опубл. 10.07.2003. URL: https://www1.fips.ru/ registers-doc-view/fips_servlet (дата обращения 01.10.2021).

9. Drilling and completion fluids customization to achieve maximum well productivity in lower burgan reservoir, case study from Kuwait field / A. Al-Ajmi, A. Al-Rushoud, A. Gohain, F. Khatib // Paper SPE 187025-MS. SPE/IATMI Asia Pacific Oil \& Gas Conference and Exhibition held. - Jakarta, 17-19 October, 2017. DOI: $10.2118 / 187025-\mathrm{MS}$.

10. Юнусов Р.Р. Буровые растворы на углеводородной основе // Интернаука. - 2020. - № 43-1 (172). - С. 72-73.

11. New technology integration of real time OBM borehole images and formation sampling while drilling. Lessons learned in challenging Deepwater Gulf of Mexico environments / R. Elghonimy, W. Pineda, G. Cedillo, M. Saidian, J. Wadsworth, D. Halverson, H. Watcharophat, S. Paul, I. Basu, A. Mayans, C. Schroeder // Paper SPWLA-5038 presented at the SPWLA 61st Annual Logging Symposium. Virtual Online Webinar. June 2020. DOI: 10.30632/spwla-5038

12. Фергестад И.М., Стракан К.Р. Разработка высококачественного бурового раствора на углеводородной основе для поисковоразведочного бурения // Нефтегазовое обозрение. Сборник III: избранные статьи из журнала «Oilfield Review». - 2014. T. 26. - № 1. - C. 4-13.

13. Преимущества применения буровых растворов на углеводородной основе при бурении нефтяных и газовых скважин / В.Ю. Гришковец, Ю.С. Давыдов, Т.А. Редкин, Л.В. Николаева, А.В. Карпиков // Известия Сибирского отделения Секции наук о Земле РАЕН. - 2013. - № 2 (43). - С. 95-102.

14. Skopec R.A., McLeod G. Recent advances in coring technology: new techniques to enhance reservoir evaluation and improve coring economics // The Journal of Canadian Petroleum Technology. - 1997. - V. 36. - № 11. - C. 22-29.

15. Изучение коллекторов по керну, отобранному при бурении на растворах с нефтяной основой / А.В. Ручкин, Л.И. Орлов, В.Г. Топорков, В.Г. Фоменко // Геология нефти и газа. 1981. - № 11. - C. 28-35.

16. Baroid Fluids Handbook. - Houston: Baroid Drilling Fluids Inc, 1998. $-506 \mathrm{p}$.

17. Warner H.R. Jr., Rathmell J.J. Mechanisms controlling filtration at the core bit for oil-based muds // SPE Drilling \& Completion. 1997. - V. 12. - № 02. - P. 111-118.

18. Fraser L.J. Field application of the all-oil drilling-fluid concept // SPE Drilling Engineering. - 1992. - V. 7. - № 01. - P. 20-24.

19. Сапожников А.А., Назаров А.П. Опыт отбора представительного керна из пологих и горизонтальных скважин при разведке и разработке месторождений комплексного сырья // Инженер-нефтяник. -2020 . - № 3. - С. 24-26.

20. Отбор керна в условиях сильно трещиноватых окремненных карбонатных коллекторов Сибирской платформы / Сираев Р.У., Вахромеев А.Г., Акчурин Р.Х., Карпиков А.В., Сверкунов С.А. // Строительство нефтяных и газовых скважин на суше и на море. - 2019. - № 6. - С. 13-20.

21. Гизатуллин Д.М. Актуальные проблемы отбора керна и их решения // Тезисы докладов Научной конференции молодых ученых и аспирантов ИФЗ РАН. - М.: Институт физики Земли им. О.Ю. Шмидта РАН, 2019. - С. 28.

22. Битнер А.К., Прокатень Е.В. Методы исследования породколлекторов и флюидов. - Красноярск: Сиб. федер. ун-т, 2018. $-224 \mathrm{c}$.

23. Development of all-oil drilling fluid for core sampling with natural fluid saturation saving in the Timan-Pechora Oil-and-Gas Province / I. Borovkova, S. Kharin, S. Malikov, I. Nekrasova, P. Khvoschin, O. Garshina, D. Kazakov // Paper SPE 191743 presented at the SPE Russian Petroleum Technology Conference. - Moscow, Russia, 15-17 October, 2018. DOI: 10.2118/191743-18RPTC-MS.

24. Опыт применения безводного бурового раствора для отбора керна на одном из месторождений Тимано-Печорской нефтегазоносной провинции / А.Д. Саетгараев, И.Л. Некрасова, П.А. Хвощин, О.В. Гаршина, Д.А. Казаков, И.С. Боровкова, С.С. Харин, С.В. Мелехин, И.А. Шилов // Строительство нефтяных и газовых скважин на суше и на море. - 2021. № 3. - C. 20-27.

25. Application of tracers to monitor fluid flow in the Snorre field: a field study / Q. Dugstad, T. Aurdal, C. Galdiga, I. Hundera, H. Torgersen // Paper SPE 56427-MS. SPE Annual Conference. Houston, 3 October, 1999. DOI: 10.2118/56427-MS.

26. Brown A., Marriott F. Use of tracers to investigate drilling-fluid invasion and oil flushing during coring // SPE Reservoir Engineering. - 1988. - № 4. - P. 1317-1322. DOI: 10.2118/16352-PA.

27. Об утверждении федеральных норм и правил в области промышленной безопасности «Правила безопасности в нефтяной и газовой промышленности». Приказ Федеральной службы по экологическому, технологическому и атомному надзору № 534 от 15.12.2020 г.: (редакция от 29.12.2020). URL: http://www.consultant.ru/document/ cons_doc_LAW_372740 (дата обращения 01.10.2021).

28. Мамяшев В.Г., Хайруллин Б.Ю., Федорцов В.В. Новые возможности петрофизического обеспечения работ на нефть и газ на основе специальных технологий отбора керна // ГеоЕвразия 2018. Современные методы изучения и освоения недр Евразии: Труды Международной геолого-геофизической конференции. - Тверь, 2018. - С. 387-391.

29. Selection of unconventional core workflow depending on field goals (Russian) / I. Karpov, T. Mamyshev, D. Kostin, V. Zhukov, K. Strizhnev // Paper SPE 182065-RU. SPE Russian Petroleum Technology Conference and Exhibition. - Moscow, 24-26 October, 2016. DOI: 10.2118/182065-RU.

30. Skopec R.A., McLeod G. Recent advances in coring technology: new techniques to enhance reservoir evaluation and improve coring economics // The Journal of Canadian Petroleum Technology. - 1997. - V. 36. - № 11. - C. 22-29.

31. Гущин В.А., Хайруллин Б.Ю. Герметизирванный керн - необходимый фактор повышения достоверности подсчета запасов углеводородов // Нефть и газ. - 2009. - № 5. - С. 36-45.

Поступила 21.10.2021 2.

Информация об авторах

Некрасова И.Л., доктор технических наук, ведущий научный сотрудник отдела буровых растворов Филиала ООО «ЛУКОЙЛ-Инжиниринг» «ПермНИПИнефть» в г. Перми.

Хвощин П.А., кандидат технических наук, начальник отдела буровых растворов Филиала ООО «ЛУКОЙЛИнжиниринг» «ПермНИПИнефть» в г. Перми.

Казаков Д.А., кандидат химических наук, старший научный сотрудник отдела буровых растворов Филиала ООО «ЛУКОЙЛ-Инжиниринг» «ПермНИПИнефть» в г. Перми.

Toponuцына И.С., кандидат химических наук, научный сотрудник отдела буровых растворов Филиала ООО «ЛУКОЙЛ-Инжиниринг» «ПермНИПИнефть» в г. Перми.

Гаршина O.B., кандидат технических наук, доцент, начальник управления технологии строительства скважин Филиала ООО «ЛУКОЙЛ-Инжиниринг» «ПермНИПИнефть» в г. Перми.

Предеин А.А., заместитель директора филиала по научной работе в области строительства скважин, Филиал ООО «ЛУКОЙЛ-Инжиниринг» «ПермНИПИнефть» в г. Перми. 
UDC 622.245 .5

\title{
METHODOLOGICAL APPROACHES TO SELECTION OF COMPOSITION AND PROPERTIES OF TECHNOLOGICAL FLUIDS USED FOR CORE SAMPLING
}

\author{
Irina L. Nekrasova ${ }^{1}$, \\ Irina.Nekrasoval@pnn.lukoil.com
}

Pavel A. Khvoshchin 1 , Pavel.Khvoschin@pnn.lukoil.com

Dmitry A. Kazakov', Dmitrij.Kazakov@pnn.lukoil.com

Irina S. Toropitsina ${ }^{1}$, Irina.Borovkova@pnn.lukoil.com

Olga V. Garshina ${ }^{1}$, Olga.Garshina@pnn.lukoil.com

\author{
Andrey A. Predein ${ }^{1}$, \\ Andrej.Predein@pnn.lukoil.com \\ 1 Branch of LLC «LUKOIL-Engineering» «PermNIPIneft», \\ 3a, Permskaya street, Perm, 614015, Russia.
}

The relevance. The main changes in the geochemical characteristics of rock samples at the core sampling are associated with an unjustified choice of the type and properties of the drilling fluids, at the storage stage - with the low quality of the core-insulating liquid. In order to obtain a representative core of the required quality, it is important to substantiate the composition and properties of drilling fluids and coreinsulating liquids, as well as other parameters of the drilling process.

The aim: to determine and propose criteria for selecting the composition and properties of drilling fluids and core-insulating fluids used for core sampling, depending on the geological conditions of application.

Objects: water-based and hydrocarbon-based drilling fluids, waterless drilling fluids, core-insulating fluids.

Methods: analysis and systematization of Russian and foreign experience in theoretical and practical research of core sampling, filtration, rheological and other research methods provided for ISO 10414-1:2008 and ISO 10414-2:2011.

Results. The analysis of the world experience in the use of drilling fluids and core-insulating liquids in various geological drilling conditions is presented. The most promising types of drilling fluids for core sampling and core-insulating fluids are determined from the point of view of preserving the initial properties of the rock. An algorithm is proposed for selecting the type and component composition of drilling fluids used for core sampling, depending on the purpose of the work, the category of rocks according to the difficulty of core sampling, and the types of geochemical studies.

\section{Key words:}

Core sampling, water-based drilling mud, hydrocarbon-based drilling mud, core-insulating liquid, geochemical core studies

\section{REFERENCES}

1. Serebrykov A.O. Sinergiya geologorazvedochnykh tekhnologiy issledovaniya prirodnykh resursov morskikh akvatoriy: monografiya [Synergy of geological exploration technologies for the study of natural resources of marine waters: monograph]. Moscow, KnoRus Publ., 2017. 228 p.

2. Ashena R., Thonhauser G. Coring methods and systems. Cham, Springer International Publ., 2018. 269 p.

3. Stewart R., Osman T., Reda T., Al-Ajmi A., Al-Rushoud A., Gohain A., Khatib F., Al-Haj H., Al-Naqa F., Al-Mutawa F., AlGharib M., Shinde H., Al-Mekhalef A. First Global successful large diameter pressurized coring application using HPWBM: Kuwait case history. The Abu Dhabi International Petroleum Exhibition \& Conference. Abu Dhabi, November 12-15, 2018. DOI: 10.2118/192694-MS.

4. Karpov Yu.I., Ayupov R.Yu., Faskhutdinov R.Sh. Improving the technique and technology of drilling with core sampling in the Nurlatsky UBR. Drilling and oil, 2006, no. 5, pp. 18-20. In Rus.

5. Yusupov I.G., Khaminov N.I., Bachkov A.P. Investigation of the technogenic impact of the primary opening of reservoirs on their reservoir properties by the selection of radial cores. Collection of scientific papers TatNIPIneft. Moscow, VNIIOENG Publ., 2009. pp. 187-197. In Rus.
6. Rathmell J.J., Gremley R.R., Tibbitts G.A. Field applications of low invasion coring. The SPE Latin America/Caribbean Petroleum Engineering Conference. Buenos Aires, April 27-29, 1994. DOI: 10.2523/27045-MS.

7. Kleshchenko I.I., Yagafarov A.K., Sharipov A.Yu., Matyushov V.G. Burovoy rastvor na uglevodorodnoy osnove [Hydrocarbon-based drilling mud]. Patent RF, no. 2208034, 2003.

8. Kurbanov Ya.M., Loginov Yu.F., Khairullin A.A., Matyushov V.E Burovoy rastvor na uglevodorodnoy osnove [Hydrocarbon-based drilling mud]. Patent RF, no. 2208035, 2003.

9. Al-Ajmi A., Al-Rushoud A., Gohain A., Khatib F. Drilling and completion fluids customization to achieve maximum well productivity in lower burgan reservoir, case study from Kuwait Field. The SPE/IATMI Asia Pacific Oil \& Gas Conference and Exhibition. Jakarta, October 7-19, 2017. DOI: 10.2118/187025-MS

10. Yunusov R.R. Burovye rastvory na uglevodorodnoy osnove [Oilbased drilling fluids]. Internauka, 2020, no. 43-1 (172), pp. 72-73.

11. Elghonimy R., Pineda W., Cedillo G., Saidian M., Wadsworth J., Halverson D., Watcharophat H., Paul S., Basu I., Mayans A., Schroeder C. New technology integration of real time OBM borehole images and formation sampling while drilling. Lessons learned in challenging Deepwater Gulf of Mexico Environments. The SPWLA 61st Annual Logging Symposium. Virtual Online Webinar. June 2020. DOI: 10.30632/spwla-5038 
12. Fergestad I.M., Strakan K.R. Razrabotka vysokokachestvennogo burovogo rastvora na uglevodorodnoy osnove dlya poiskovorazvedochnogo bureniya [Development of high quality oil-based drilling fluid for exploration drilling]. Neftegazovoye obozreniye, Sbornik III: izbrannyye stati iz zhurnala «Oilfield Review», 2014, vol. 26, no. 1, pp. 4-13.

13. Grishkovets V.Yu., Davydov Yu.S., Redkin T.A., Nikolaeva L.V., Karpikov A.V. Preimushchestva primeneniya burovykh rastvorov na uglevodorodnoy osnove pri burenii neftyanykh i gazovykh skvazhin [Advantages of using oil-based drilling fluids for drilling oil and gas wells]. Izvestiva Sibirskogo otdeleniya Sektsii nauk o Zemle RAYEN, 2013, no. 2 (43), pp. 95-102.

14. Skopec R.A., McLeod G. Recent advances in coring technology: new techniques to enhance reservoir evaluation and improve coring economics. The Journal of Canadian Petroleum Technology, 1997, vol. 36, no. 11, pp. 22-29.

15. Ruchkin A.V., Orlov L.I., Toporkov V.G., Fomenko V.G. Izuchenie kollektorov po kernu, otobrannomu pri burenii na rastvorakh s neftyanoy osnovoy [Study of reservoirs by core sampled during drilling with oil-based mud]. Geologiva nefti $i$ gaza, 1981, no. 11, pp. 28-35.

16. Baroid Fluids Handbook. Houston, Baroid Drilling Fluids Inc Publ., 1998. $506 \mathrm{p}$.

17. Warner H.R., Rathmell J.J. Mechanisms controlling filtration at the core bit for oil-based muds. SPE Drilling \& Completion, 1997, vol. 12 , no. 02, pp. 111-118.

18. Fraser L.J. Field application of the all-oil drilling-fluid concept. SPE Drilling Engineering, 1992, vol. 7, no. 01, pp. 20-24.

19. Sapozhkov A.A., Nazarov A.P. Technology of a representative core selection from sliding and horizontal wells during exploration and development of complex raw material deposits. Oil engineer 2020, no. 3, pp. 24-26. In Rus.

20. Siraev R.U., Vakhromeev A.G., Akchurin R.H., Karpikov A.V., Sverkunov S.A. Ore sampling in conditions of strongly fractured silicified carbonate collectors of the Siberian platform. Construction of oil and gas wells on land and sea, 2019, no. 6, pp. 13-20. In Rus.

21. Gizatullin D.M. Aktualnye problemy otbora kerna i ikh resheniya [Topical problems of coring and their solutions]. Tezisy dokladov Nauchnoy konferentsii molodykh uchenykh i aspirantov IFZ RAN [Scientific conference of young scientists and graduate students of the Institute of Physics of the Earth RAS]. Moscow, 2019. pp. 28.

22. Bitner A.K., Prokaten E.V. Metody issledovaniya porodkollektorov i flyuidov [Methods for the study of reservoir rocks and fluids]. Krasnoyarsk, Siberian federal University Publ., 2018. $224 \mathrm{p}$.

23. Borovkova I., Kharin S., Malikov S., Nekrasova I., Khvoschin P., Garshina O., Kazakov D. Development of all-oil drilling fluid for core sampling with natural fluid saturation saving in the TimanPechora Oil-and-Gas Province. The SPE Russian Petroleum Tech- nology Conference. Russia, Moscow, October 15-17, 2018. DOI: 10.2118/191743-18RPTC-MS.

24. Saetgaraev A.D., Nekrasova I.L., Khvoshchin P.A., Garshina O.V., Kazakov D.A., Borovkova I.S., Kharin S.S., Melekhin S.V., Shilov I.A. Opyt primeneniya bezvodnogo burovogo rastvora dlya otbora kerna na odnom iz mestorozhdeniy Timano-Pechorskoy neftegazonosnoy provintsii [Experience in the use of anhydrous drilling mud for coring at one of the fields of the Timan-Pechora oil and gas province]. Stroitelstvo neftyanykh i gazovykh skvazhin na sushe i na more, 2021, no. 3, pp. 20-27.

25. Dugstad Q., Aurdal T., Galdiga C., Hundera I., Torgersen H. Application of tracers to monitor fluid flow in the Snorre field: a field study. The SPE Annual Conference. Houston, October 03, 1999. DOI: $10.2118 / 56427-\mathrm{MS}$

26. Brown A., Marriott $F$. Use of tracers to investigate drilling-fluid invasion and oil flushing during coring. SPE Reservoir Engineering, 1988, no. 4, pp. 1317-1322. DOI: 10.2118/16352-PA.

27. Ob utverzhdenii federalnykh norm i pravil $v$ oblasti promyshlennoy bezopasnosti «Pravila bezopasnosti $v$ neftyanoy $i$ gazovoy promyshlennosti». Prikaz Federalnoy sluzhby po ekologicheskomu, tekhnologicheskomu i atomnomu nadzoru № 534 ot 15.12 .2020 [On the approval of federal norms and rules in the field of industrial safety «Safety rules in the oil and gas industry». Order of the Federal Service for Environmental, Technological and Nuclear Supervision No. 534, 15.12.2020]. Available at: http://www.consultant.ru/document/ cons_doc_LAW_372740 (accessed 1 October 2021).

28. Mamyashev V.G., Khayrullin B.Yu., Fedortsovyu V.V. Novye vozmozhnosti petrofizicheskogo obespecheniya rabot na neft i gaz na osnove spetsialnykh tekhnologiy otbora kerna [New opportunities for petrophysical support of oil and gas operations based on special technologies for coring]. GeoEvraziya 2018. Sovremennye metody izucheniya i osvoeniya nedr Evrazii. Trudy mezhdunarodnoy geologo-geofizicheskoy konferentsii [International Geological and Geophysical Conference. GeoEurasia 2018. Modern Methods for the Study and Development of the Subsoil of Eurasia]. Tver, 2018. pp. 387-391.

29. Karpov I., Mamyshev T., Kostin D., Zhukov V., Strizhnev K. Selection of unconventional core workflow depending on field goals (Russian). The SPE Russian Petroleum Technology Conference and Exhibition. Moscow, October 24-26, 2016. DOI: 10.2118/182065-RU

30. Skopec R.A., McLeod G. Recent advances in coring technology: new techniques to enhance reservoir evaluation and improve coring economics. The Journal of Canadian Petroleum Technology, 1997, vol. 36, no. 11, pp. 22-29.

31. Guschin V.A., Hairullin B.YU. Pressurized core sampling - a necessary factor for improvement of petroleum reserves calculation reliability. Oil and gas, 2009, no. 5, pp. 36-45. In Rus.

Received: 21 October 2021.

\section{Information about the authors}

Irina L. Nekrasova, Dr. Sc., leading researcher, Branch of LLC «LUKOIL-Engineering» «PermNIPIneft».

Pavel A. Khvoshchin, Cand. Sc., head of department, Branch of LLC «LUKOIL-Engineering» «PermNIPIneft».

Dmitry A. Kazakov, Cand. Sc., senior researcher, Branch of LLC «LUKOIL-Engineering» «PermNIPIneft».

Irina S. Toropitsina, Cand. Sc., researcher, Branch of LLC «LUKOIL-Engineering» «PermNIPIneft».

Olga V. Garshina, Cand. Sc., head of department, Branch of LLC «LUKOIL-Engineering» «PermNIPIneft».

Andrey A. Predein, associate director, Branch of LLC «LUKOIL-Engineering» «PermNIPIneft». 